Portland State University

PDXScholar

\title{
The Atmosphere can be a Source of Certain Water Soluble Volatile Organic Compounds in Urban Streams
}

\author{
Scott J. Kenner \\ South Dakota School of Mines and Technology \\ David A. Bender \\ U.S. Geological Survey \\ James F. Pankow \\ Portland State University \\ John S. Zogorski \\ U.S. Geological Survey
}

Follow this and additional works at: https://pdxscholar.library.pdx.edu/chem_fac

Part of the Chemistry Commons, and the Water Resource Management Commons Let us know how access to this document benefits you.

\section{Citation Details}

Kenner, S. J., Bender, D. A., Pankow, J. F., \& Zogorski, J. S. (2014). The Atmosphere can be a Source of Certain Water Soluble Volatile Organic Compounds in Urban Streams. JAWRA Journal of the American Water Resources Association.

This Article is brought to you for free and open access. It has been accepted for inclusion in Chemistry Faculty Publications and Presentations by an authorized administrator of PDXScholar. Please contact us if we can make this document more accessible: pdxscholar@pdx.edu. 


\title{
THE ATMOSPHERE CAN BE A SOURCE OF CERTAIN WATER SOLUBLE VOLATILE ORGANIC COMPOUNDS IN URBAN STREAMS ${ }^{1}$
}

\author{
Scott J. Kenner, David A. Bender, James F. Pankow, and John S. Zogorski ${ }^{2}$
}

\begin{abstract}
Surface water and air volatile organic compound (VOC) data from 10 U.S. Geological Survey monitoring sites were used to evaluate the potential for direct transport of VOCs from the atmosphere to urban streams. Analytical results of 87 VOC compounds were screened by evaluating the occurrence and detection levels in both water and air, and equilibrium concentrations in water $\left(C_{w}{ }^{s}\right)$ based on the measured air concentrations. Four compounds (acetone, methyl tertiary butyl ether, toluene, and $m$ - \& $p$-xylene) were detected in more than $20 \%$ of water samples, in more than $10 \%$ of air samples, and more than $10 \%$ of detections in air were greater than long-term method detection levels (LTMDL) in water. Benzene was detected in more than 20\% of water samples and in more than $10 \%$ of air samples. Two percent of benzene detections in air were greater than one-half the LTMDL in water. Six compounds (chloroform, $p$-isopropyltoluene, methylene chloride, perchloroethene, 1,1,1-trichloroethane, and trichloroethene) were detected in more than $20 \%$ of water samples and in more than $10 \%$ of air samples. Five VOCs, toluene, $m$ - \& $p$-xylene, methyl tert-butyl ether (MTBE), acetone, and benzene were identified as having sufficiently high concentrations in the atmosphere to be a source to urban streams. MTBE, acetone, and benzene exhibited behavior that was consistent with equilibrium concentrations in the atmosphere.
\end{abstract}

(KEY TERMS: organic chemicals; nonpoint source pollution; rivers/streams; urban areas; MTBE; benzene; acetone; Henry's Law; atmospheric deposition; air and water equilibrium.)

Kenner, Scott J., David A. Bender, James F. Pankow, and John S. Zogorski, 2014. The Atmosphere Can Be a Source of Certain Water Soluble Volatile Organic Compounds in Urban Streams. Journal of the American Water Resources Association (JAWRA) 50(5): 1124-1137. DOI: 10.1111/jawr.12181

\section{INTRODUCTION}

Exposure to volatile organic compounds (VOCs) can be a human health concern because they may cause adverse health effects at relatively low microgram per liter concentrations. The water quality criteria and toxicity levels for VOCs are summarized in
Rowe et al. (1997). Although the concentrations of VOCs in small urban streams are typically well below human or aquatic health standards and guidelines (Bender et al., 2009), effects due to long-term exposure to concentrations below drinking water standards and to mixtures of VOCs are unknown (Carter et al., 2008). VOCs are released into the environment during their production, distribution, storage,

\footnotetext{
${ }^{1}$ Paper No. JAWRA-12-0193-P of the Journal of the American Water Resources Association (JAWRA). Received September 20, 2012; accepted December 19, 2013. (c) 2014 American Water Resources Association. Discussions are open until six months from print publication.

${ }^{2}$ Professor (Kenner), Civil and Environmental Engineering, South Dakota School of Mines \& Technology, 501 E. St. Joseph St., Rapid City, South Dakota 57701; Hydrologist (Bender) and Supervisory Hydrologist (Zogorski), Water Science Center, U.S. Geological Survey, Rapid City, South Dakota 57702; and Professor (Pankow), Chemistry and Civil and Environmental Engineering, Portland State University, Portland, Oregon 97207 (E-Mail/Kenner: scott.kenner@sdsmt.edu).
} 
handling, and use and can enter both surface water and groundwater supplies from many point and nonpoint sources (Lopes and Bender, 1998). Once in the environment, VOCs can be transported between air, surface water, or groundwater depending on environmental conditions, individual compound properties, and concentrations. Baehr et al. (2001) found that atmospheric methyl tert-butyl ether (MTBE) concentrations were high enough in southern New Jersey to cause detection in shallow groundwater at concentrations greater than $0.05 \mu \mathrm{g} / \mathrm{l}$ which would indicate a possibility for atmospheric transport to surface water. The numerous point and nonpoint sources and physical and chemical properties of VOCs have resulted in their frequent detection in ambient air (Lopes and Bender, 1998; Pankow et al., 1998, 2003; Baehr et al., 1999), groundwater (Squillace et al., 1996, 1999; Baehr et al., 1999; Moran et al., 2005), and surface water (Baehr and Zapecza, 1998; Lopes and Bender, 1998; Lundgren and Lopes, 1999; Bender et al., 2000, 2009). Detection frequencies for VOCs range from $20.7 \%$ (PIPT, $p$-isopropyltoluene) to $83 \%$ (toluene) in urban streams and from $64.6 \%$ (trichloroethene) to $89.0 \%$ (toluene) in urban air. With documentation of the frequent occurrence and distribution of VOCs throughout the environment, emphasis is being placed on identifying and characterizing sources and pathways for VOCs within the hydrologic cycle (Zogorski et al., 2006). To reduce and or control the concentration levels of VOCs in surface water, it is essential to identify and understand the role of different sources.

Age dating of groundwater using chlorofluorocarbons is based on the premise that the atmosphere can serve as a source to groundwater through infiltrating precipitation (Plummer et al., 1993) and through the vadose zone by gas-phase diffusion (Weeks et al., 1982). Various studies have evaluated transport of VOCs from the atmosphere to shallow groundwater by means of precipitation infiltration and direct gas-phase diffusion (Pankow et al., 1997; Squillace et al., 1997; Baehr et al., 1999; Johnson et al., 2003). These studies present that VOCs can move from shallow groundwater back to the atmosphere through diffusion, vaporization, and evapotranspiration. Pankow et al. (1997, 2003) infer that VOCs can volatilize from surface water and shallow groundwater to the atmosphere or move from the atmosphere to surface water and groundwater.

Atmospheric deposition of toxic chemicals (including some VOCs) has been a topic of extensive study as part of the Great Lakes Water Quality Agreement to characterize atmospheric loadings relative to other loading sources (Hoff et al., 1996). These studies have identified that gas absorption for polychlorinated biphenols (PCBs considered semivolatile), in comparison to particulate deposition at the air-water interface, is the most important transport mechanism in urban areas and becomes increasingly important as distance increases from urban areas (Hoff et al., 1996; MacKay and Bentzen, 1997; Baker, 2000). VOCs are nearly $100 \%$ in the gas phase, thus gas absorption at the air-water interface is the primary transport mechanism. However, these studies also identified volatilization as an important gas transfer process from surface waters to the atmosphere, indicating a net loss from the surface of lakes for some semivolatile organic compounds (PCBs, dieldrin, hexachlorobenzene, dichlorodiphenyldichloroethene, phenanthrene, and pyrene) and a net gain to the surface of lakes for others ( $p, p^{\prime}$-dichlordiphenyltrichoroethane and alpha-hexachlorocyclohexane) due to seasonal variability in these processes. Hoff et al. (1996) identified the need to have short-term concurrent measurements in both water and air for more accurate estimation of mass transfer rates.

Bender et al. (2000) evaluated the atmospherewater interaction of chloroform, toluene, and methyl tert-butyl ether (MTBE) in two small perennial urban streams and suggested that the atmosphere may be a source of MTBE but not a source of chloroform or toluene.

Equilibrium between a stream and the atmosphere can be thought to occur in three ways: (1) the stream is contaminated with a VOC, outgases to the atmosphere, reaches equilibrium with the atmosphere, and sets the atmospheric concentration; (2) the atmosphere is contaminated with a VOC, ingases to the stream, reaches equilibrium with the stream, and sets the stream concentration; or (3) some combination of 1 and 2, whereby equilibrium is only a momentary condition as concentrations change due to variable loadings. It is relatively easy to discount the first and third possibilities due to the relative volume and thus storage capacity of a stream vs. the atmosphere because the atmosphere has storage capacity orders of magnitude larger than the stream. The hypothesis here is that when the stream water is at or below equilibrium with the atmosphere (i.e., surface water is undersaturated relative to the air concentration) for a given VOC, it is possible that the atmosphere is serving as an important source of that VOC to surface water through gas partitioning. Also, when a stream is contaminated to a concentration level greater than the equilibrium with the atmosphere, the VOC will outgas until it comes back to equilibrium.

The purpose of this study was to characterize the role of the atmosphere as a potential source of VOCs to small, perennial urban streams that do not have substantial point-source discharges in their watersheds. VOC data from surface water and ambient air 
samples collected as part of the U.S. Geological Survey's National Water Quality Assessment (NAWQA) Program, herein called monitoring sites, were used in the analyses. Details of the site selection and sampling design of these urban stream monitoring sites, which in NAWQA are referred to as urban intensive fixed sites, are provided elsewhere (Lopes and Price, 1997). The analysis consists of (1) a screening evaluation of detections in both water and air, (2) a comparison of ambient concentrations measured in surface water to water-equilibrium concentrations, (3) a statistical comparison of paired ambient surface water concentrations and equivalent water-equilibrium concentrations, and (4) a statistical and graphical evaluation of seasonal variability.

\section{METHODS}

Surface water sampling followed guidelines established for the collection of samples for low-level determination of VOCs (Shelton, 1997). Grab samples were collected at the mid-depth and centroid of the stream (Bender et al., 2000) at a section with uniform well-mixed flow. A total of 323 surface water samples were collected and analyzed for 87 VOC analytes. The analytical method for surface water samples is described in detail by Connor et al. (1998) and summarized by Bender et al. (2000). The method consisted of purge-and-trap gas chromatography/mass spectrometry (GC/MS) using a 25-ml water sample. Compounds were identified by strict criteria, quantified to sub- $\mu \mathrm{g} / \mathrm{l}$ levels, and quantifications below calibration standards were qualified as estimated (Oblinger Childress et al., 1999; Bender et al., 2000). Long-term method detection levels (LTMDL) for water analyses ranged from 0.008 to $2.9 \mu \mathrm{g} / \mathrm{l}$ for trichloroethene (TCE) and acetone, respectively (Connor et al., 1998).

The air samples were collected and analyzed for 87 VOC analytes according to the method presented by Pankow et al. (1998). The total number of air samples analyzed for each parameter ranged from 296 to 302 . Briefly, each sample was obtained using two sorbent cartridges: (1) a low volume ( 1.5 l) cartridge containing $50 \mathrm{mg}$ of Carbotrap B followed by $280 \mathrm{mg}$ of Carboxen 1000 (Supelco Inc., Bellefonte, Pennsylvania), and (2) a high volume ( $\sim 5$ l) cartridge containing $180 \mathrm{mg}$ of Carbotrap B followed by $70 \mathrm{mg}$ of Carboxen 1000 (Supelco Inc.). Sample air was drawn through the cartridges using a programmable sampling pump (224-PCXR8, SKC Inc., Eighty Four, Pennsylvania). Samples were collected over a time period that ranged from 1 to $24 \mathrm{~h}$ using a flow rate of $30-50 \mathrm{ml} / \mathrm{min}$ (Pankow et al., 2003) and a periodic on/ off sampling cycle to achieve the desired sample volume. Analyses were completed by adsorption/thermal desorption GC/MS. The VOC analytes are listed in Pankow et al. (1998). The VOC analytes ranged in volatility from dichlorodifluoromethane (CFC-12, $H=13.2)$ to $1,2,3$-trichlorobenzene $(H=0.0358)$ and method detection limits (MDLs) ranged from 0.02 to 0.06 part per billion by volume for the 87 analytes (Pankow et al., 1998).

Monitoring program characteristics of surface water and ambient air sites are presented in Table 1. The air samples at the LINJ and SACR sites were collected at a fixed time interval that did not coincide with the dates of water samples. The water and air samples were paired based on the closest sampling dates. The LINJ site was characterized by three air monitoring locations (Coles Farm, Rowan College, and Turnersville) distributed throughout the Great Egg Harbor River watershed. The absolute time differences between surface water and air samples for the LINJ site ranged from zero to seven days with an average difference of three days. The SACR air monitoring site was colocated with the California Air Resources Board site at Roseville and within the Arcade Creek watershed. The absolute time differences between surface water and air samples for the SACR site ranged from zero to eight days with an average difference of 4.8 days. Concurrent water and air samples were collected at the other monitoring sites (ACAD, DELR, MIAM, NECB, SANA, and UIRB) (Lopes and Price, 1997).

The distribution or partitioning of a compound between air and water commonly is described by the dimensionless Henry's Gas Law constant $(H=H /$ $R T$ ), which is the ratio of Henry's Gas Law constant $(H)$ to the product of the universal gas constant $(R)$ and temperature $(T)$. The dimensionless form defines the number of molecules (i.e., mass) dissolved in air $\left(C_{a}\right)$ vs. water $\left(C_{w}\right)$. For values greater than $(>) 1$ $\left(C_{a}>C_{w}\right)$, the compound is predominately in the air phase, and for values less than $(<) 1\left(C_{a}<C_{w}\right)$, the compound generally is dissolved in the water. Values of $H$ for toluene and MTBE are 0.2267 and 0.0260, respectively, and support the findings of Bender et al. (2000). The magnitude and direction of transport depends on the relative concentrations in air and surface water. Air concentrations $\left\{C_{a}\right.$ (moles per cubic meter $\left.\left.\left[\mathrm{mol} / \mathrm{m}^{3}\right]\right)\right\}$ were converted to an equivalent water-equilibrium concentration $\left(C_{w}{ }^{s}\left[\mathrm{~mol} / \mathrm{m}^{3}\right]\right)$ on the basis of the dimensionless Henry's Law constant $(H)$ corrected for temperature using the van't Hoff relation (Denbigh, 1966). Specifically: 


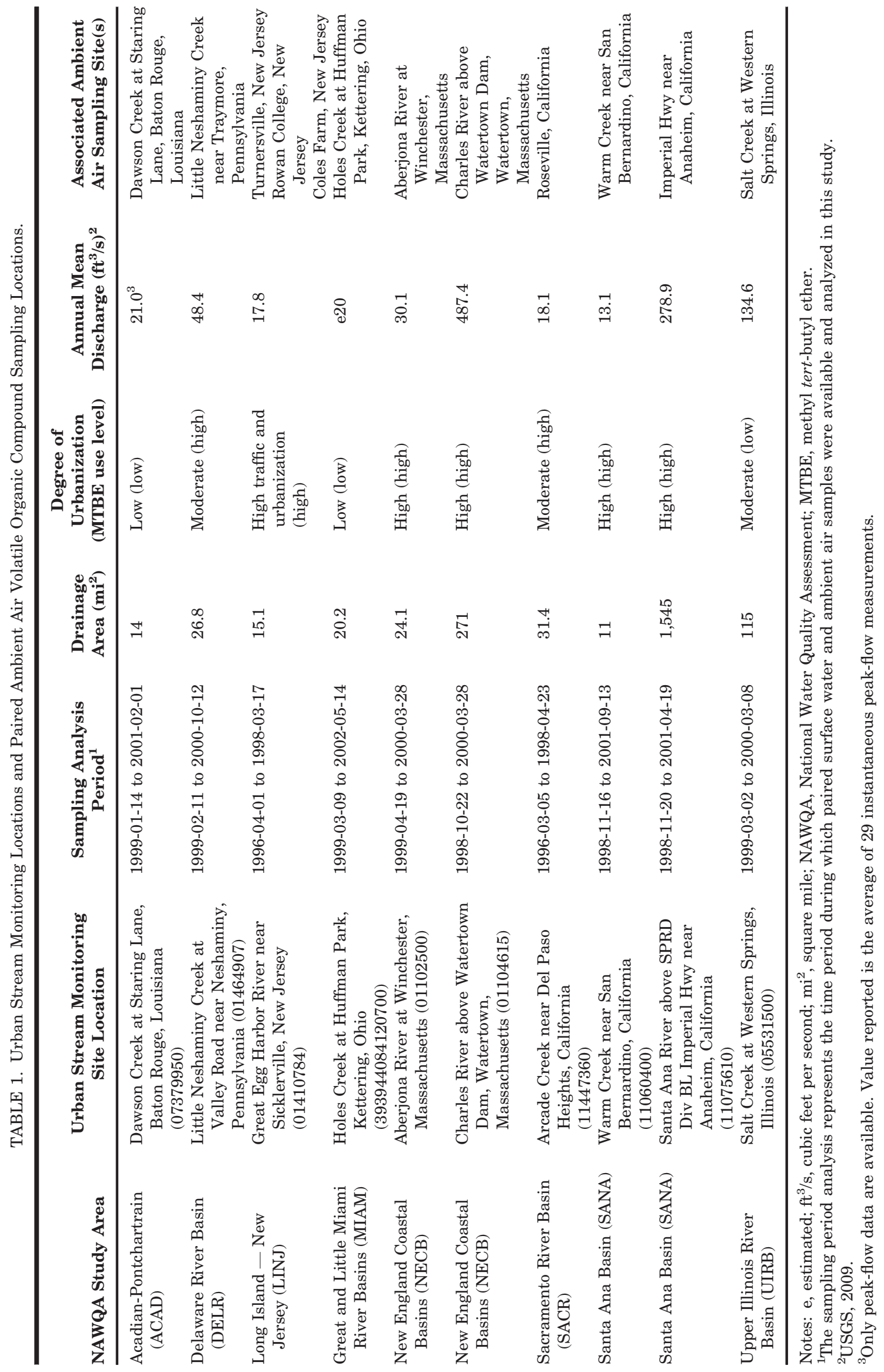




$$
\begin{aligned}
& C_{w}^{s}=\frac{C_{a}}{H^{\prime}} \\
& H^{\prime}=\frac{H}{\mathrm{RT}} \\
& H=\exp \left(A-\frac{B}{T}\right)
\end{aligned}
$$

where $H$ has dimensions of Pascal cubic meters per mole $\left(\mathrm{Pa}-\mathrm{m}^{3} / \mathrm{mol}\right)$ or joules per mole $(\mathrm{J} / \mathrm{mol}), A$ and $B$ are compound-specific regression coefficients, $R$ is the gas constant $(=8.3145 \mathrm{~J} / \mathrm{mol}$ per degree Kelvin $[\mathrm{J} /$ $\left.\mathrm{mol}{ }^{\circ} \mathrm{K}\right]$ ), and $T$ is the temperature in degrees Kelvin $\left({ }^{\circ} \mathrm{K}\right)$. By analogy with water saturation by minerals (Pankow, 1991), the saturation index (SI) for a given VOC from air is defined as

$$
\mathrm{SI}=\frac{C_{w}}{C_{w}^{s}}
$$

where $C_{w}$ is the measured surface water concentration.

Statistical comparisons of paired surface water/ equivalent water-equilibrium concentrations $\left(C_{w} / C_{w}{ }^{s}\right)$ were made using a Wilcoxon rank-sum test (Insightful Corporation, 2001) for paired data. The test was run for the null hypotheses $\left(\mathrm{H}_{\mathrm{o}}\right)$ that the median concentrations for both datasets are equal $\left(C_{w}=C_{w}{ }^{s}\right)$ and for three alternative hypotheses $\left(\mathrm{H}_{\mathrm{a}}\right)$ : (1) the median $C_{w}{ }^{s}$ is not equal to the median $C_{w}$, (2) the median $C_{w}$ is greater than the median $C_{w}{ }^{s}$, and (3) the median $C_{w}$ is less than the median $C_{w}{ }^{s}$.

Seasonality in both $C_{w}$ and $C_{w}{ }^{s}$ was evaluated by comparing the concentrations during the cold period (October through March) and the warm period (April through September) also using a Wilcoxon rank-sum test. When the $p$-value for the calculated $z$ statistic is $>0.05$ a strong statistical difference is not indicated between the cold and warm period concentrations; subsequently not an indication of seasonal differences. When the $p$-value is $\leq 0.05$, the difference between the cold and warm period samples indicates statistically significant seasonal differences.

\section{SCREENING EVALUATION OF COMPOUNDS}

Analytical results of the 87 VOCs were screened by evaluating the occurrence, $C_{\mathrm{w}}$, and $C_{w}{ }^{s}$. For determinations of VOCs at all sites, the following evaluation was done to identify compounds that have a potential persistent equilibrium between surface water and air. First, each VOC was placed in one of four air-occurrence categories: (1) detected in more than $10 \%$ of air samples (number of compounds $[n]=44)$, (2) detected in less than $10 \%$ of air samples $(n=25)$, (3) not detected in air $(n=19)$, and (4) not analyzed in air $(n=3)$. VOCs in categories 1 and 2 were further grouped based on $C_{w}{ }^{s}$ : (a) for more than $10 \%$ of detections in air, $C_{w}{ }^{s}$ was greater than the LTMDL in water (atmosphere is possible source), (b) for more than $2 \%$ of detections in air, $C_{w}{ }^{s}$ was greater than one-half the LTMDL in water (infrequently detected at marginal concentrations), and (c) for less than $1 \%$ of detections in air, $C_{w}{ }^{s}$ was greater than one-half the LTMDL in water (rarely detected at marginal concentrations).

In addition, each VOC was grouped into five surface water occurrence categories: (1) detected in more than $20 \%$ of surface water samples $(n=14$, detected frequently in water), (2) detected in more than $10 \%$ but less than $20 \%$ of surface water samples $(n=11$, detected in water), (3) detected in less than $10 \%$ of surface water samples $(n=24$, not detected frequently in water), (4) not detected in surface water samples $(n=38)$, and (5) not analyzed in surface water samples $(n=4)$.

From the screening evaluation, acetone, MTBE, $m$ - \& $p$-xylene, and toluene were detected in more than $20 \%$ of surface water samples and in more than $10 \%$ of air samples, and more than $10 \%$ of the $C_{w}{ }^{s}$ values were greater than the LTMDL in water. Benzene was detected in more than $20 \%$ of surface water samples and in more than $10 \%$ of air samples; more than $2 \%$ of the $C_{w}{ }^{s}$ values were greater than $0.5^{*}$ LTMDL in water. Six VOCs - chloroform, methylene chloride, perchloroethene (PCE), PIPT, 1,1,1trichloroethane (1,1,1-TCA), and TCE were detected in more than $20 \%$ of surface water samples and in more than $10 \%$ of air samples; less than $1 \%$ of the $C_{w}{ }^{s}$ values were greater than 0.5*LTMDL in water.

\section{DEGREE OF SATURATION AND COMPARISON OF CONCENTRATIONS}

For the 11 compounds identified in the screening evaluation as having a potential persistent equilibrium between surface water and air, the level of saturation in surface water relative to air was calculated for each case when a given VOC was detected simultaneously in corresponding water and air samples. When $\mathrm{SI}=1$, the stream is in equilibrium with the air. The degree to which SI $\neq 1$ is a measure of the 
degree of departure from equilibrium. For example, a $\mathrm{SI}=1.5$ indicates that the stream is supersaturated by $50 \%$ and the VOC can volatilize to the atmosphere. Conversely when the $\mathrm{SI}<1$ the stream is undersaturated and the VOC can diffuse from the atmosphere to surface water. Persistence of $\mathrm{SI}=1$ would indicate that the atmosphere is sustaining equilibrium in the surface water. A summary of the percent detection in surface water and air, median SI value, percentage of SI values $<1$, and $H$ is presented in Table 2. These 11 compounds have relatively high detection frequencies in both surface water and air.

The compounds 1,1,1-TCA, PIPT, chloroform, PCE, and TCE have median SI values $>1$ and no SI values $<1$; for these compounds, the atmosphere is not a primary source. The concentrations of these VOCs in streams are sustained above equilibrium by other sources and will tend to volatilize to the atmosphere. Methylene chloride, toluene, and $m$ - \& $p$-xylene form the next grouping with median SI values of 3.7, 2.9, and 2.3, respectively, and percent SI values $<1$ of $14.3,20.3$, and 12.0, respectively. For these compounds, the atmosphere could be a primary source at times, but for the majority of the time, other sources are likely dominant.

A probable scenario for these compounds would be that other sources increase the concentration to above equilibrium, during which time volatilization occurs until the stream has reached equilibrium. At this point volatilization and absorption are balanced and the atmosphere is not a substantial source but sets the stream concentration at the atmospheric level. MTBE, benzene, and acetone have median SI values of $1.9,1.3$, and 1.1 respectively, and percent SI values $<1$ of $44.6,32.4$, and 43.5 , respectively. The order of magnitude represented in Figure 1 and in Table 2 demonstrate the variability of concentrations in the atmosphere and in surface water; and that these are changing all the time. The state of equilibrium does not likely persist for any extended time as they respond to changes in the atmospheric concentration and temperature. But the condition for absorbtion, SI $<1$, does exist for a significant period of time to indicate the atmosphere is a source.

Statistical analysis of the paired surface water/ equivalent water-equilibrium concentrations $\left(C_{w} / C_{w}{ }^{s}\right)$ for acetone, benzene, $m$ - \& $p$-xylene, MTBE, and toluene (i.e., data that were not reported as an NA [not analyzed] or $<$ [not detected]) is presented in Table 3. For toluene and $m$ - \& $p$-xylene, surface water concentrations were not equal to equivalent water-equilibrium concentrations and tended to be greater $(p<0.001)$. Surface water MTBE concentrations tended to be greater than equivalent water-equilibrium concentrations at $\alpha=0.05$ and were not equal at $\alpha=0.10$ (Table 3). In contrast, surface water concentrations for acetone and benzene were not significantly different from equivalent water-equilibrium concentrations $(p>0.05)$. The statistical analyses support the interpretation of SI values.

These characteristics can be observed in plots of SI vs. $C_{w}$ (Figure 1) and box plots of SI for each compound (Figure 2). When SI consistently plots near one, vs. $C_{w}$ (Figure 1) (flat slope), this indicates persistent equilibrium with the atmosphere and support the atmosphere as a consistent source (acetone and benzene). Changes in SI values with $C_{w}$ (Figure 1) indicate a dominant source other than the atmosphere. A discontinuity in the slope, where the data indicate no slope at lower concentrations and an increasing slope at higher concentrations, indicates different sources under different conditions such as changing flows or seasons. Similarly, Figure 2 shows that the SI values for acetone and benzene centered around equilibrium $(\mathrm{SI}=1.0$ ); although the median for MTBE is near equilibrium there are more values

TABLE 2. Summary of Screening Characteristics for Selected VOC Compounds, Ranked by Median SI.

\begin{tabular}{|c|c|c|c|c|c|c|}
\hline \multirow[b]{2}{*}{ Compound } & \multicolumn{2}{|c|}{ Percent Detection } & \multirow[b]{2}{*}{ Median SI } & \multirow[b]{2}{*}{$\% \mathrm{SI}<1$} & \multirow[b]{2}{*}{$\boldsymbol{H}^{\prime}$} & \multirow[b]{2}{*}{ Reference for $H^{\prime}$ Values } \\
\hline & Surface Water & Air & & & & \\
\hline Acetone & 38.4 & 77.4 & 1.1 & 43.5 & 0.0016 & Rathbun and Tai (1988) \\
\hline Benzene & 34.3 & 92.7 & 1.3 & 32.4 & 0.2218 & Leighton and Calo (1981) \\
\hline MTBE & 71.0 & 89.9 & 1.9 & 44.6 & 0.0260 & Robbins et al. (1993) \\
\hline$m$ - \& $p$-Xylene & 29.7 & 97.6 & 2.3 & 12.0 & 0.2472 & Dewulf et al. (1995) \\
\hline Toluene & 82.7 & 97.2 & 2.9 & 20.3 & 0.2267 & Dewulf et al. (1995) \\
\hline Methylene chloride & 22.5 & 73.4 & 3.7 & 14.3 & 0.1305 & Leighton and Calo (1981) \\
\hline 1,1,1-Trichloroethane & 26.5 & 96.0 & 36.6 & 0.0 & 0.7964 & Leighton and Calo (1981) \\
\hline$p$-Isopropyltoluene & 20.4 & 90.7 & 76.6 & 0.0 & 0.0910 & Mackay et al. (1992) \\
\hline Chloroform & 67.9 & 84.6 & 77.9 & 0.0 & 0.1523 & Dewulf et al. (1995) \\
\hline Perchloroethene & 47.8 & 93.5 & 90.5 & 0.0 & 0.6511 & Leighton and Calo (1981) \\
\hline Trichloroethene & 50.6 & 75.3 & 412.7 & 0.0 & 0.3959 & Leighton and Calo (1981) \\
\hline
\end{tabular}

Note: \%, percent; $H^{\prime}$, dimensionless Henry's Law constant at $25^{\circ} \mathrm{C}$; SI, saturation index; VOC, volatile organic compounds; MTBE, methyl tert-butyl ether. 

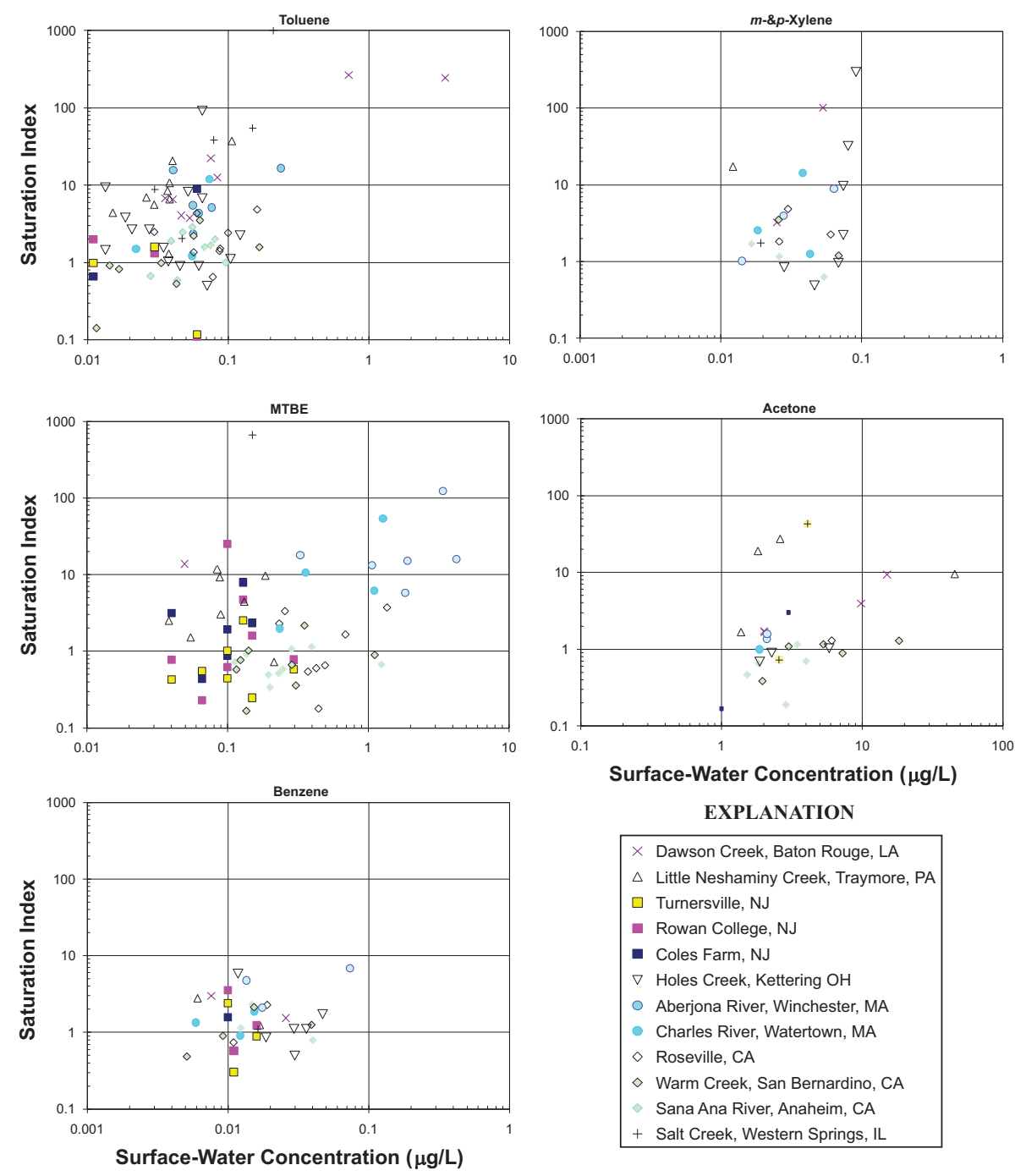

EXPLANATION

\begin{tabular}{|ll|}
\hline$\times$ & Dawson Creek, Baton Rouge, LA \\
$\triangle$ & Little Neshaminy Creek, Traymore, PA \\
$\square$ & Turnersville, NJ \\
$\square$ & Rowan College, NJ \\
$\square$ & Coles Farm, NJ \\
$\nabla$ & Holes Creek, Kettering OH \\
& Aberjona River, Winchester, MA \\
- & Charles River, Watertown, MA \\
$\diamond$ & Roseville, CA \\
$\diamond$ & Warm Creek, San Bernardino, CA \\
& Sana Ana River, Anaheim, CA \\
+ & Salt Creek, Western Springs, IL \\
\hline
\end{tabular}

FIGURE 1. Saturation Index vs. Measured Surface Water Concentration $\left(C_{w}\right)$ for Samples When Both Water and Air Detections Occurred Simultaneously.

TABLE 3. Results of Wilcoxon Rank-Sum Test Comparing the Surface Water Concentration with the Equivalent Water-Equilibrium Concentration for Paired Water/Air Data.

\begin{tabular}{|c|c|c|c|c|c|c|}
\hline \multirow[b]{4}{*}{ Compound } & \multicolumn{6}{|c|}{ Wilcoxon Rank-Sum Test Null Hypotheses, $\mathrm{H}_{\mathrm{o}}: C_{w}=C_{w}{ }^{s}$} \\
\hline & \multicolumn{6}{|c|}{ Alternative Hypotheses } \\
\hline & \multicolumn{2}{|c|}{ 1. $\mathbf{H}_{\mathbf{a}} \neq \mathbf{0}\left(C_{w} \neq C_{w}{ }^{s}\right)$} & \multicolumn{2}{|c|}{ 2. $\mathbf{H}_{\mathrm{a}}>\mathbf{O}\left(C_{w}>C_{w}{ }^{s}\right)$} & \multicolumn{2}{|c|}{ 3. $\mathbf{H}_{\mathrm{a}}>\mathbf{O}\left(C_{w}<C_{w}{ }^{s}\right)$} \\
\hline & $z$ & $p$-Value & $z$ & $p$-Value & $z$ & $p$-Value \\
\hline Toluene & 6.2891 & $<0.0001$ & 6.2874 & $<0.0001$ & 6.2909 & 1.0 \\
\hline$m$ - \& $p$-Xylene & 3.3762 & 0.0007 & 3.3762 & 0.0004 & 3.3956 & 0.9997 \\
\hline MTBE & 1.7928 & 0.073 & 1.7928 & 0.0365 & 1.7975 & 0.9639 \\
\hline Acetone & 0.2856 & 0.7752 & 0.2856 & 0.3876 & 0.3076 & 0.6208 \\
\hline Benzene & 1.3923 & 0.1638 & 1.3923 & 0.0819 & 1.4046 & 0.9199 \\
\hline
\end{tabular}

Notes: $C_{w}$, surface water concentration; $C_{w}{ }^{s}$ equivalent water-equilibrium concentration; MTBE, methyl tert-butyl ether.

Shaded cells represent rejection of $\mathrm{H}_{\mathrm{o}}$, and accepting $\mathrm{H}_{\mathrm{a}}$. 


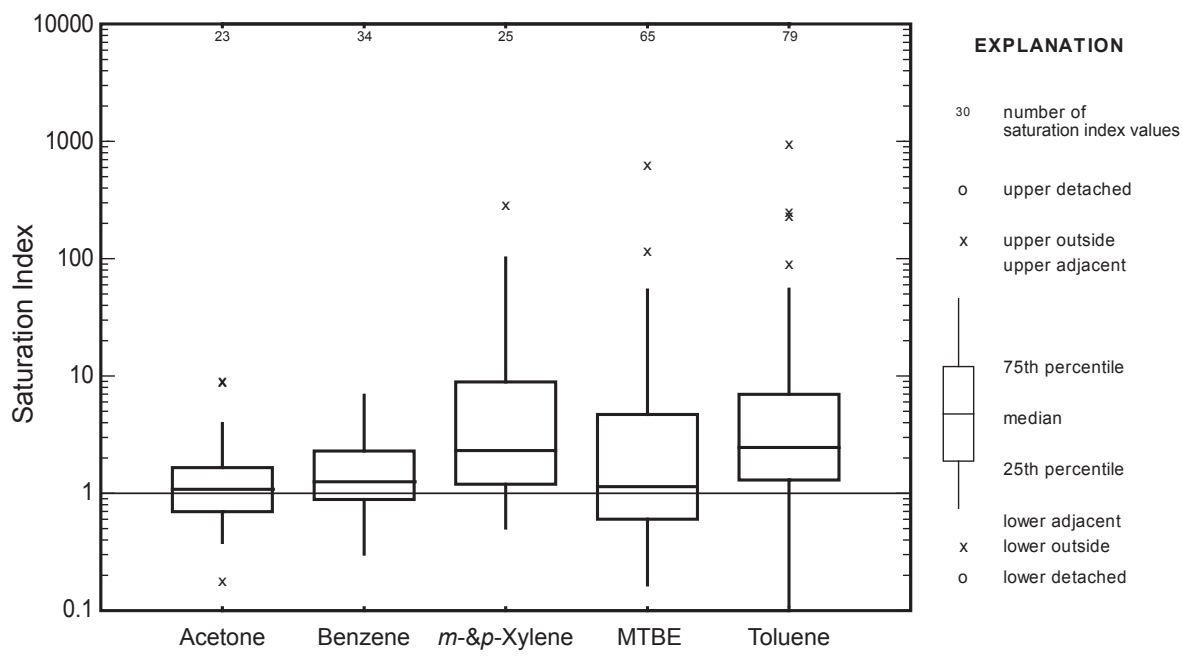

FIGURE 2. Box Plots of Calculated Saturation Index Values from All Sites for Acetone, Benzene, $m$ - \& $p$-Xylene, MTBE, and Toluene.

above equilibrium. For $m$ - \& $p$-xylene and toluene more than $75 \%$ of the data are greater than equilibrium.

\section{Seasonal Covariation}

The data (for all monitoring sites) in two seasonal periods (cold period: October through March and the warm period: April through September) were independently compared for the five VOCs indicating the atmosphere as a potential source using a Wilcoxon rank-sum test (Table 4). For toluene, no seasonal pattern was observed at the ACAD, DELR, or SANA (Warm Creek) sites, and $C_{w} \geq C_{w}{ }^{s}$ for toluene and thus do not indicate the air as a potential source at these sites. At the LINJ and SACR sites, the $C_{w}{ }^{s}$ values for toluene presented a strong seasonal pattern but the $C_{w}$ values did not indicate a strong seasonal pattern. This again indicates that the atmosphere is not a consistent potential source of toluene to streams. MTBE at the LINJ, SACR, and DELR sites demonstrated seasonality for both the $C_{w}$ and $C_{w}{ }^{s}$ values. At the SANA site, neither the $C_{w}$ values nor the $C_{w}{ }^{s}$ values indicated seasonality. For MTBE, all sites had $C_{w}$ values equal or nearly equal to the $C_{w}{ }^{s}$ values, which indicate the atmosphere as a potential source of MTBE to streams throughout the year. For benzene, the Wilcoxon rank-sum test indicated a strong seasonal pattern for both the $C_{w}$ and $C_{w}{ }^{s}$ values (Table 4). Also, the $C_{w}{ }^{s}$ values tended to be $\geq C_{w}$ values, which supports the atmosphere as a potential source of benzene to streams. For acetone no seasonal pattern was indicated for either the $C_{w}$ or $C_{w}{ }^{s}$ values (Figure 3). The $C_{w}{ }^{s}$ values tended to be $\geq C_{w}$ values for acetone, which indicates the atmosphere as a potential source for acetone to streams.

Box plots for MTBE, acetone, and benzene at selected sites are included to show the seasonal characteristics (Figure 3). These plots show the general seasonal relations observed for MTBE, benzene, and acetone. Observed seasonality was consistent among sites for MTBE and benzene. The strongest indication of seasonality was observed in the $C_{w}{ }^{s}$ values for

TABLE 4. Results of Wilcoxon Rank-Sum Test on Surface Water and Equivalent Water-Equilibrium Concentrations Grouped into Warm (April-September) and Cold (October-March) Time Periods.

\begin{tabular}{|c|c|c|c|c|c|c|}
\hline \multirow[b]{2}{*}{ Compound } & \multicolumn{3}{|c|}{ Surface Water Concentration $\left(C_{w}\right)$} & \multicolumn{3}{|c|}{$\begin{array}{l}\text { Equivalent Water-Equilibrium Concentration } \\
\qquad\left(C_{w}{ }^{s}\right)\end{array}$} \\
\hline & $\boldsymbol{z}$ & $p$-Value & Result & $z$ & $p$-Value & Result \\
\hline Toluene $(n=26)$ & 1.1697 & 0.2421 & No seasonal difference & 4.325 & $<0.0001$ & Strong seasonal difference \\
\hline$m$ - \& $p$-Xylene $(n=8)$ & -1.6984 & 0.0894 & Weak seasonal difference & 2.2079 & 0.0272 & Seasonal difference \\
\hline $\operatorname{MTBE}(n=25)$ & 3.9775 & 0.0001 & Strong seasonal difference & 4.3296 & $<0.0001$ & Strong seasonal difference \\
\hline Acetone $(n=14)$ & 0.504 & 0.6143 & No seasonal difference & -0.7559 & 0.4497 & No seasonal difference \\
\hline Benzene $(n=21)$ & 2.982 & 0.0029 & Strong seasonal difference & 3.1717 & 0.0015 & Strong seasonal difference \\
\hline
\end{tabular}

Notes: MTBE, methyl tert-butyl ether.

All seasonal differences result from higher concentrations during the cold season, October through March. 
MTBE - LINJ

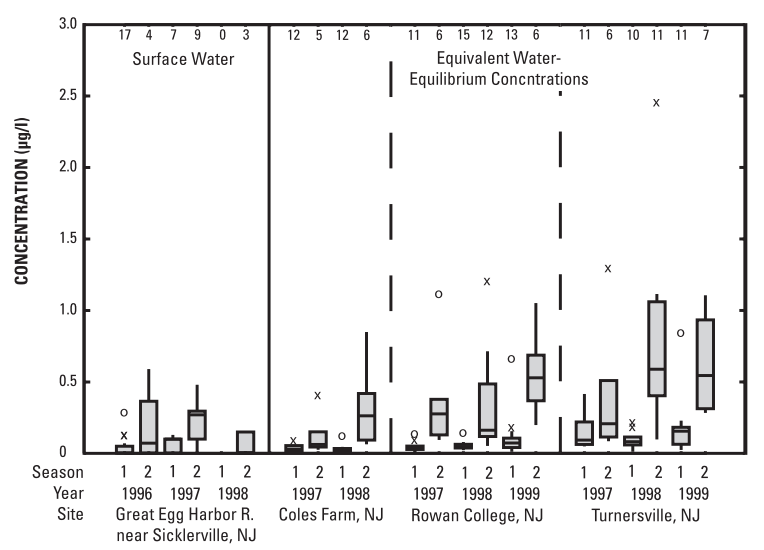

Benzene - LINJ

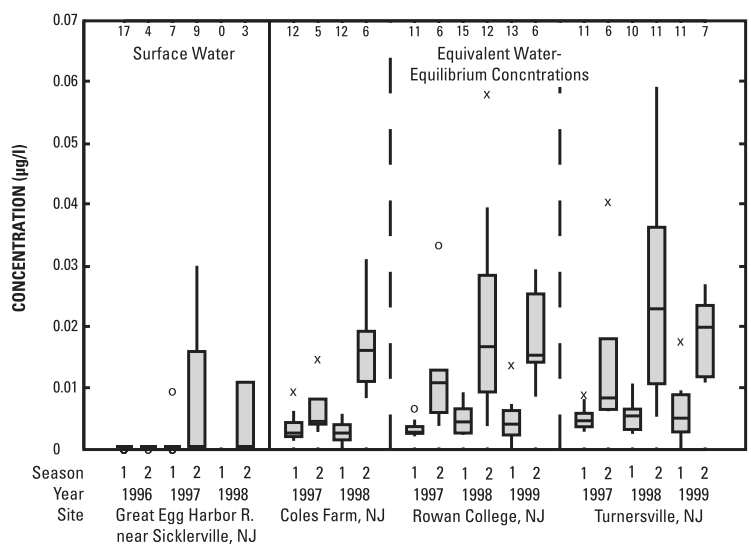

ACETONE - ACAD

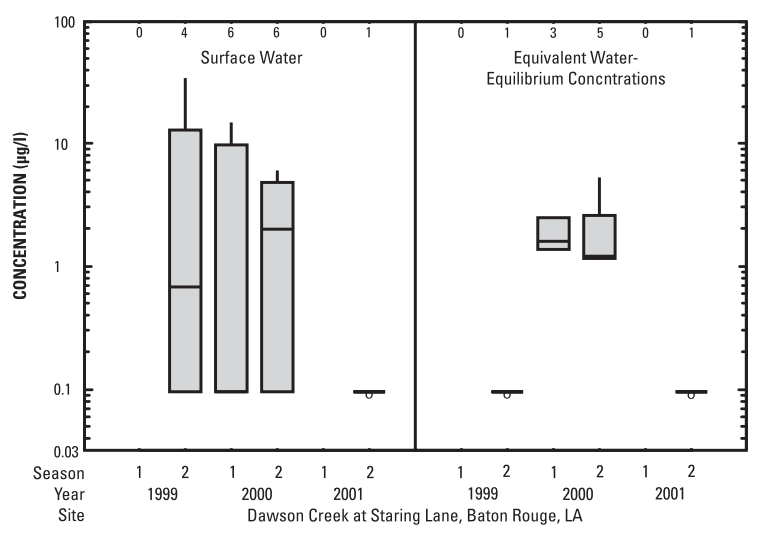

MTBE - SACR

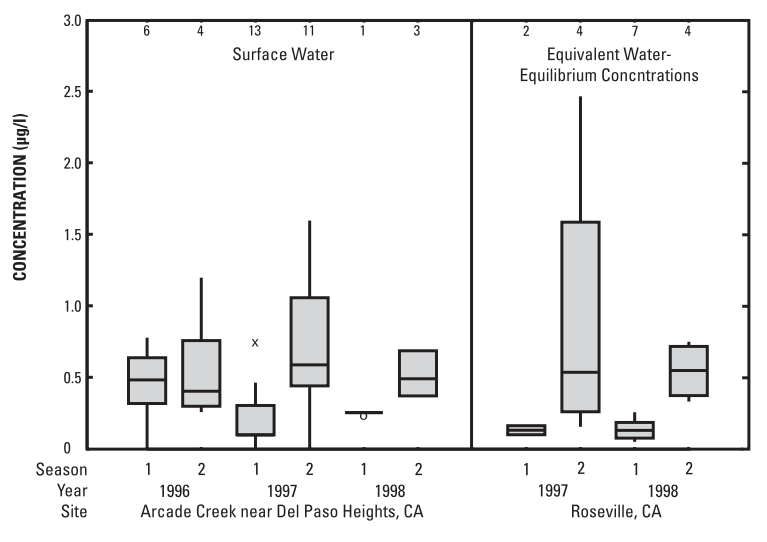

Benzene - MIAM

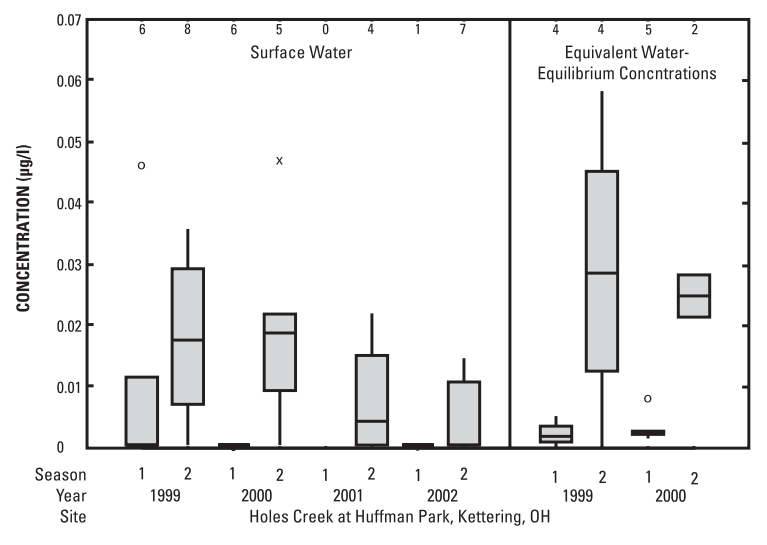

ACETONE - DELR

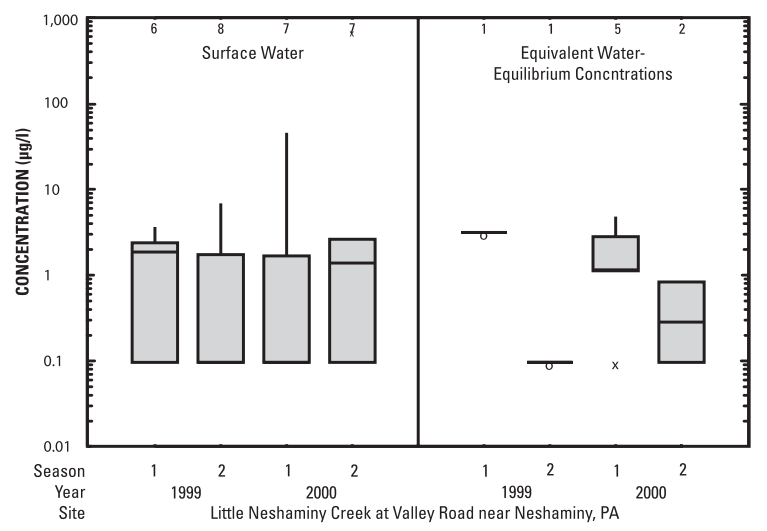

\footnotetext{
EXPLANATION

30 number of

samples

upper detached
upper outside

goth percentile

75th percentile

median

25th percentile

10th percentile

lower outside

lower detached
}

FIGURE 3. Seasonal Box Plots of Surface Water $\left(C_{w}\right)$ and Equivalent Water-Equilibrium Concentrations $\left(C_{w}{ }^{s}\right)$ for Selected Sites and Compounds, Season 1 (warm period April-September) and Season 2 (cold period October-March) ( $\mu \mathrm{g} / \mathrm{l})$. 
The Atmosphere Can Be a Source of Certain Water Soluble Volatile Organic Compounds in Urban Streams

TABLE 5. Number of Groundwater Samples, Number of Detections, Percentage of Detections for Selected Compounds, and the Monitoring Site Watersheds within Which Detections Occurred.

\begin{tabular}{|c|c|c|c|c|c|}
\hline Compound & $\begin{array}{c}\text { Number } \\
\text { of Samples }\end{array}$ & $\begin{array}{c}\text { Number of } \\
\text { Non-Detections }\end{array}$ & $\begin{array}{l}\text { Number of } \\
\text { Detections }\end{array}$ & $\begin{array}{l}\text { Percentage } \\
\text { of Detections }\end{array}$ & $\begin{array}{c}\text { Monitoring Site } \\
\text { Watersheds with Detections }\end{array}$ \\
\hline Toluene & 30 & 22 & 8 & 26.7 & SACR, SANA \\
\hline$m$ - \& $p$-Xylene & 30 & 26 & 4 & 13.3 & SACR, SANA \\
\hline MTBE & 30 & 25 & 5 & 16.7 & DELR, LINJ, NECB \\
\hline Acetone & 30 & 30 & 0 & 0 & None \\
\hline Benzene & 30 & 29 & 1 & 3.3 & SANA \\
\hline
\end{tabular}

Note: SACR, Sacramento River Basin; SANA, Santa Ana Basin; DELR, Delaware River Basin; LINJ, Long Island — New Jersey; NECB, New England Coastal Basins; MTBE, methyl tert-butyl ether.

MTBE and benzene associated with the LINJ site (Coles Farm, Rowan College, and Turnersville).

In general, the LTMDL makes it difficult to interpret a strong seasonality in the surface water concentration data due to too many censored data points in seasons when concentrations could be much lower; however, one distinction is the higher $C_{w}$ values that coincide with the higher $C_{w}{ }^{s}$ values, primarily during winter.

\section{Shallow Groundwater Concentrations}

Stream monitoring sites were selected to avoid point sources. Few samples were collected during periods of stormwater runoff thus the stream concentrations of VOCs primarily represent base-flow conditions. When considering the atmosphere as a sustained source to these small urban streams, the occurrence of VOCs in nearby shallow groundwater also needs to be considered as a possible contributing source. VOC sample results from shallow wells closest to the stream monitoring sites were queried from the NAWQA database for shallow groundwater in urban areas (USGS, 2008) to identify and consider shallow groundwater as a potential source. The total number of samples, number of detections, percentage of detections, and the watersheds within which groundwater detections occurred are provided in Table 5. The groundwater sites were selected visually using geographic information system plots of well locations and the watershed boundaries for the monitoring sites. Sites with shallow groundwater monitoring locations within their watershed area are DELR, LINJ, NECB, SACR, and SANA. For the sites with shallow groundwater monitoring wells, the number of wells within any one watershed ranged from one to three with multiple samples collected at each well. Results from a total of 30 samples were available for each compound.

Overall, the groundwater data in proximity to these sites were sparse. The key observation from the groundwater data is that the compounds that have
$C_{w}$ values $>C_{w}{ }^{s}$ values $-\mathrm{MTBE}$, toluene, and $m$ - \& $p$-xylene - were detected in more than $10 \%$ of samples $(16.7,26.7$, and $13.3 \%$, respectively) in the groundwater (Table 5). For the compounds that have $C_{w}$ values generally equal to $C_{w}{ }^{s}$ values, no compounds were detected in groundwater except for MTBE. Shallow groundwater concentrations of VOCs can affect concentrations in streams, serving as a consistent source of VOCs. From the available shallow groundwater data, toluene and $m$ - \& $p$-xylene were detected in 26.7 and $13.3 \%$ of the samples, respectively, and the SACR and SANA sites had groundwater detections within their watershed areas. Shallow groundwater is a potential source for toluene and $m$ - \& $p$-xylene and is a probable source other than the atmosphere for these compounds and sites. MTBE was detected in $16.7 \%$ of samples, and the DELR, LINJ, and NECB sites had groundwater detections within their watersheds. Benzene was detected in $3.3 \%$ of samples, with one detection in the watershed for the SANA site. Acetone was not detected in shallow groundwater.

\section{DISCUSSION}

Many VOCs have been detected frequently in urban streams and it is necessary to identify and characterize the source of these VOCs to reduce or minimize their concentration levels. From the preliminary screening based on occurrence in water, occurrence in air, and comparison of $C_{w}{ }^{s}$ with $C_{w}, 5$ VOCs (out of 87 analyzed) were identified as having the atmosphere as a potential source - toluene, $m$ $\& p$-xylene, MTBE, acetone, and benzene. Table 6 provides the median SI value and the percentage of SI values $<1$ for the monitoring sites and compounds for which air/stream equilibrium is indicated by the SI values discussed above.

Overall, $C_{w}$ values tended to be greater than the calculated $C_{w}{ }^{s}$ values for toluene and $m$ - \& $p$-xylene 
Kenner, Bender, Pankow, and Zogorski

TABLE 6. Median SI Values and Percentage of SI Values Less Than One, by Site and Compound.

\begin{tabular}{|c|c|c|c|c|c|c|c|c|}
\hline \multirow[b]{2}{*}{ Compound } & \multicolumn{8}{|c|}{ Median SI Values (percentage of SI values $<1$ ) for Urban Stream Monitoring Sites } \\
\hline & ACAD & DELR & LINJ & MIAM & NECB & SACR & SANA & UIRB \\
\hline Toluene & $10(0.0 \%)$ & $7(0.0 \%)$ & $1(50.0 \%)$ & $2(20.0 \%)$ & $5(0.0 \%)$ & $2(12.5 \%)$ & $2(47.1 \%)$ & $38(0.0 \%)$ \\
\hline$m$ - \& $p$-Xylene & 52 & 17 & - & $2(28.6 \%)$ & $3(0.0 \%)$ & $2(0.0 \%)$ & $1(20.0 \%)$ & 2 \\
\hline MTBE & 14 & $4(12.5 \%)$ & $1(55.0 \%)$ & - & $14(0.0 \%)$ & $1(50.0 \%)$ & $1(76.5 \%)$ & 662 \\
\hline Acetone & $3(0.0 \%)$ & 6 & - & $1(66.7 \%)$ & $1(33.3 \%)$ & - & $1(60.0 \%)$ & 1 \\
\hline Benzene & 2 & 2 & $1(50.0 \%)$ & $1(33.3 \%)$ & $2(16.7 \%)$ & 2 & $1(42.9 \%)$ & 1 \\
\hline
\end{tabular}

Notes: MTBE, methyl tert-butyl ether; SI, saturation index; _, no paired data available; SACR, Sacramento River Basin; SANA, Santa Ana Basin; DELR, Delaware River Basin; LINJ, Long Island - New Jersey; NECB, New England Coastal Basins; UIRB, Upper Illinois River Basin; MIAM, Great and Little Miami River Basins; ACAD, Acadian-Pontchartrain.

When there were less than three (3) data pairs, only the median SI is reported. Shaded cells indicate compounds and sites where the atmosphere is a potential source.

(Figure 2). The overall median SI for toluene was 3 with $20.3 \%$ of SI values $<1$ (Table 2 ) and a maximum SI value of 1,000 at the UIRB site. The overall median SI for $m$ - \& $p$-xylene was 2 with $12.0 \%$ of SI values $<1$ (Table 2) and a maximum SI value of 302 at the MIAM site. The Wilcoxon rank-sum test indicated that $C_{w}$ values for both toluene and $m$ - \& $p$-xylene were not equal to and tended to be greater than the respective $C_{w}{ }^{s}$ values $(\alpha=0.05)$ (Table 3). However, the $C_{w}{ }^{s}$ plots and SI values indicate that at times some sites are at or near equilibrium conditions. For example, the LINJ, MIAM, SACR, and SANA sites had median SI values of 1 or 2 for toluene (Table 6) with an average of $32.4 \%$ of SI values $<1$. In contrast, the UIRB, ACAD, DELR, and NECB sites had median SI values for toluene of $38,10,7$, and 5 , respectively, with no SI values $<1$. The SI values indicate that equilibrium conditions may exist for toluene but are variable among sites.

The MIAM, NECB, SACR, SANA, and UIRB sites had median SI values of 1,2 , or 3 for $m$ - \& $p$-xylene (Table 6) with an average of $9.7 \%$ of SI values $<1$, whereas the DELR and ACAD sites had median SI values of 17 and 52 , respectively. In general, the $C_{w}$ values for $m$ - \& $p$-xylene were not equal to and tended to be greater than the $C_{w}{ }^{s}$ values at the ACAD, DELR, NECB, SACR, and UIRB sites. However, for $\alpha=0.10, C_{w}$ and $C_{w}{ }^{s}$ values were not statistically different from each other at the MIAM and SANA sites.

Overall, $C_{w}$ values for MTBE tended to be equal to or greater than $C_{w}{ }^{s}$ values. Considering all sites, the median SI for MTBE was 2 with $44.6 \%$ of SI values $<1$ (Table 2). The Wilcoxon rank-sum test indicated that $C_{w}$ values were not different from $C_{w}{ }^{s}$ values at $\alpha=0.05$ but would reject that hypothesis at $\alpha=0.10$ (Table 3). The $C_{w}$ values tended to be greater than $C_{w}{ }^{s}$ values at $\alpha=0.05$. Similar to toluene and $m-\&$ $p$-xylene, equilibrium conditions for MTBE varied among the sites. The LINJ, SACR, and SANA sites had the largest percentages of samples with SI values
$<1$, and the median SI at each site was 1 (Table 6). The Wilcoxon rank-sum test on these three sites alone indicated that $C_{w}$ values for MTBE were not different from $C_{w}{ }^{s}$ values. The ACAD, NECB, and DELR sites had median SI values for MTBE of 14, 14 , and 4, respectively, and the UIRB site had only one measurement with an SI value of 662 . This would tend to indicate other significant sources than the atmosphere. MTBE concentrations can be related to the percent volume of MTBE in gasoline (Zogorski et al., 2006). Table 1 identifies high-use (>3\% volume in gasoline) and low-use ( $<3 \%$ volume in gasoline) areas. Higher surface water concentrations are associated with high-use areas. The relatively high MTBE concentrations in the Aberjona River also can be associated with a leaking underground storage tank (Robinson et al., 2004).

The $C_{w}$ values for acetone and benzene tended to be generally equal to $C_{w}{ }^{s}$ values (Figure 2). The overall median SI values for both compounds were 1 with $43.5 \%$ and $32.4 \%$ of the values $<1$, respectively (Table 2). The Wilcoxon rank-sum test indicated that the $C_{w}$ values for both acetone and benzene were not different from the $C_{w}{ }^{s}$ values with a high degree of significance (Table 3). The DELR site had a median SI value of 6 for acetone (Table 6). Statistical analysis on grouped acetone data for the ACAD and DELR sites indicated that $C_{w}$ values were not equal to the $C_{w}{ }^{s}$ values $(\alpha=0.10)$ and tended to be greater $(\alpha=0.05)$. For benzene, all sites tended to be consistently at or near equilibrium (Figure 1).

The atmosphere as a potential direct source of VOCs to streams is supported when $C_{w}{ }^{s} \geq C_{w}$ and a similar seasonal pattern is observed in both. Observation of seasonal patterns was limited by the number, duration, and frequency of paired data, and the LTMDL for water analyses. Strong seasonal patterns were indicated in both the $C_{w}{ }^{s}$ and $C_{w}$ data for MTBE and benzene (Table 4). The VOC $m$ - \& $p$-xylene indicated a seasonal difference for the $C_{w}{ }^{s}$ data but a weak seasonal difference for the $C_{w}$ data. 
Acetone indicated no seasonal difference for either $C_{w}{ }^{s}$ or $C_{w}$ data. Toluene indicated a strong seasonal difference for $C_{w}{ }^{s}$ data but no seasonal difference for the $C_{w}$ data.

Hornbuckle et al. (1994), Hoff et al. (1992, 1996), and Baker (2000) identified seasonal patterns in the concentrations of semivolatile compounds (such as PCBs) in air and water over the Great Lakes. They generally indicate lower concentrations in surface waters during the summer when volatilization rates are highest and subsequent higher concentrations in surface waters during winter months. MacKay and Bentzen (1997) and Baker (2000) indicate that the overall annual concentrations in air and surface water show a net transfer from the atmosphere to the Great Lakes. The seasonal characteristics of the data presented here are similar. The general observed seasonal pattern is high concentrations during the cold period (October-March) and low concentrations during the warm period (April-September). During the low concentration period (warm period), the $C_{w}$ values commonly decrease to less than the LTMDL. The $C_{w}$ values during the cold period commonly were greater than the LTMDL and were approximately equal to the $C_{w}{ }^{s}$ values indicating the atmosphere as a possible source.

Two conditions that promote the diffusion of VOCs from the atmosphere to urban streams are (1) there are no other substantial sources (stormwater, shallow groundwater, or surface discharges) at any time or frequency to the stream, and (2) the atmosphere must have relatively constant concentration levels for extended periods of time. The overall situation that would promote these conditions is where air is subject to high emissions or sources of VOCs, typically over highly urbanized areas. VOCs in the air mass over these areas can move by advection or diffusion to surrounding areas, which typically are less urbanized and subject to fewer sources. If the concentration in the air is sustained, certain VOCs can diffuse to surface water. Smaller streams will tend to reach equilibrium concentrations more quickly than larger streams (Pankow et al., 1996). The data used for the evaluation also indicate that, depending on when samples were collected, $C_{w}$ values could be slightly greater or less than $C_{w}{ }^{s}$ values. For the three compounds identified (acetone, benzene, and MTBE), this means that $C_{w}$ values could be slightly above equilibrium as the concentration in the air mass is lowering and or being transported out of the area or that when the $C_{w}$ value is slightly less than the $C_{w}{ }^{s}$ value, the stream concentration may be lagging behind the air concentration. This cyclical action relates to the global movement and distribution of persistent organic pollutants described by Wania and MacKay (1996), where the surface of the earth (surface water and ground) acts as the media in a fractional distillation process. As VOC concentrations become more sustained over highly urbanized areas, surrounding air masses will have higher sustained concentrations and can serve as a more prominent source to smaller streams.

\section{CONCLUSION}

Three of the VOCs evaluated - acetone, benzene, and MTBE - indicate that the atmosphere is a potential consistent source to urban streams at the monitored sites. These compounds also have relatively low dimensionless Henry's Law values, which support the tendency to diffuse from air to water. For other VOCs, the atmosphere can sustain a low concentration in surface water when other sources are not dominant. However, specific conditions causing equilibrium do vary and make it difficult to extrapolate the analysis of equilibrium conditions from site to site and thus identify the need for local and regional monitoring of surface water and air for detailed analysis.

The concentration of VOCs in water and air tends to be seasonal due to both loading and temperature variability. Depending on local conditions, the atmosphere can serve as a source year-round but tends to be a stronger source during winter months.

As VOC concentrations in the atmosphere are sustained and/or increased, the atmosphere will continue to be a potential important source to those small streams that do not have large point-source discharges. Further analysis of atmospheric-stream relations requires very specific paired monitoring of surface water and ambient air over multiple seasons and characterization of local and regional loadings. As various agencies (city, state, and federal) deal with total maximum daily loads, it will be important to recognize the atmosphere as a potential source of VOCs.

\section{ACKNOWLEDGMENTS}

Any use of trade, product, or firm names is for descriptive purposes only and does not imply endorsement by the U.S. Government.

\section{LITERATURE CITED}

Baehr, A.L., E.G. Charles, and R.J. Baker, 2001. Methyl tert-Butyl Ether Degradation in the Unsaturated Zone and the Relation 
Kenner, Bender, Pankow, and Zogorski

between MTBE in the Atmosphere and Shallow Ground Water. Water Resources Research 37:223-233.

Baehr, A.L., P.E. Stackelberg, and R.J. Baker, 1999. Evaluation of the Atmosphere as a Source of Volatile Organic Compounds in Shallow Groundwater. Water Resources Research 35(1):127136.

Baehr, A.L. and O.S. Zapecza, 1998. Methyl tert-Butyl Ether (MTBE) and Other Volatile Organic Compounds in Lakes in Byram Township, Sussex County, New Jersey, Summer 1998. U.S. Geological Survey Water-Resources Investigations Report 984264. http://pubs.er.usgs.gov/usgspubs/wri/wri984264.

Baker, J.E., 2000. Exchange of Atmospheric Chemicals with Urban Surface Water: Controls on Long-Term Response Times. Workshop on Using Models to Develop Air Toxics Reduction Strategies: Lake Michigan as a Test Case, Milwaukee, Wisconsin, November 8-9, 2000.

Bender, D.A., G.C. Delzer, C.V. Price, and J.S. Zogorski, 2009. Occurrence of Volatile Organic Compounds in Selected Urban Streams in the United States, 1995-2003. U.S Geological Survey Scientific Investigations Report 2009-5203, 87 pp. http://pubs. water.usgs.gov/sir20095203.

Bender, D.A., J.S. Zogorski, W. Luo, J.F. Pankow, M.S. Majewski, and R.J. Baker, 2000. Atmosphere-Water Interaction of Chloroform, Toluene, and MTBE in Small Perennial Urban Streams. Air \& Waste Management Association Conference and Exposition, 93rd, Salt Lake City, Utah, June 18-22. CD-ROM Proceedings, $11 \mathrm{pp}$.

Carter, J.M., W.W. Lapham, and J.S. Zogorski, 2008. Occurances of Volatile Organic Compounds in Aquifers of the United States. Journal of the American Water Resources Association 44(2):399416.

Connor, B.F., D.L. Rose, M.C. Noriega, L.K. Murtagh, and S.R. Abney, 1998. Methods of Analysis by the U.S. Geological Survey National Water Quality Laboratory-Determination of 86 Volatile Organic Compounds in Water by Gas Chromatography/Mass Spectrometry, Including Detections Less Than Reporting Limits. U.S. Geological Survey Open-File Report 97-829. http://pubs.er. usgs.gov/usgspubs/ofr/ofr97829.

Denbigh, K.G., 1966. The Principles of Chemical Equilibrium: With Applications in Chemistry and Chemical Engineering (Fourth Edition). Cambridge University Press, Cambridge, Massachusetts.

Dewulf, J., D. Drijvers, and H. Van Langenhove, 1995. Measurement of Henry's Law Constant as Function of Temperature and Salinity for the Low Temperature Range. Atmospheric Environment 29(3):232-331.

Hoff, R.M., D.C.G. Muir, and N.P. Grift, 1992. Annual Cycle of Polychlorinated Biphenyls and Organohalogen Pesticides in Air in Southern Ontario. 2. Atmospheric Transport and Sources. Environmental Science and Technology 26(2):276-283.

Hoff, R.M., W.M.J. Strachan, C.W. Sweet, C.H. Chan, M. Shackleton, T.F. Bidleman, K.A. Brice, D.A. Burniston, S. Cussion, D.F. Gatz, K. Harlin, and W.H. Schroeder, 1996. Atmospheric Deposition of Toxic Chemicals to the Great Lakes: A Review of Data through 1994. Atmospheric Environment 30(20):3505-3527.

Hornbuckle, K.C., J.D. Jeremiason, C.W. Sweet, and S.J. Eisenreich, 1994. Seasonal Variations in Air-Water Exchange of Polychlorinated Biphenyls in Lake Superior. Environmental Science and Technology 28(8):1491-1501.

Insightful Corporation, 2001. S-Plus 6 for Windows Guide to Statistics, Volume 1. Insightful Corporation, Seattle, Washington, D.C.

Johnson, R.L., R.B. Thoms, and J.S. Zogorski, 2003. Effects of Daily Precipitation and Evapotransporation Patterns on Flow and VOC Transport to Groundwater along a Watershed Flow Path. Environmental Science and Technology 37(21):4944-4954.

Leighton, D.T. and J.M. Calo, 1981. Distribution Coefficients of Chlorinated Hydrocarbons in Dilute Air-Water Systems for
Groundwater Contamination Applications. Journal of Chemical and Engineering Data 26(4):382-385.

Lopes, T.J. and D.A. Bender, 1998. Nonpoint Sources of Volatile Organic Compounds in Urban Areas-Relative Importance of Land Surfaces and Air. Environmental Pollution 101:221-230.

Lopes, T.J. and C.V. Price, 1997. Study Plan for Urban Stream Indicator Sites for the National Water-Quality Assessment Program. U.S. Geological Survey Open-File Report 97-25. http:// pubs.er.usgs.gov/usgspubs/ofr/ofr9725.

Lundgren, R.F. and T.J. Lopes, 1999. Occurance, Distribution, and Trends of Volatile Organic Compounds in the Ohio River and Major Tributaries, 1987-96. U.S. Geological Survey WaterResources Investigations Report 99-4257. http://pubs.er.usgs. gov/usgspubs/wri/wri994257.

MacKay, D. and E. Bentzen, 1997. Short Communication: The Role of the Atmosphere in Great Lakes Contamination. Amospheric Environment 31(23):4045-4047.

Mackay, D., W.Y. Shiu, and K.C. Ma, 1992. Illustrated Handbook of Physical-Chemical Properties of Environmental Fate for Organic Chemicals, v. 1, Monoaromatic Hydrocarbons, Chlorobenzenes, and PCBs. Lewis Publishers, Chelsea, Michigan.

Moran, M.J., J.S. Zogorski, and P.J. Squillace, 2005. MTBE and Gasoline Hydrocarbons in Groundwater of the United States. Ground Water 43(4):615-627.

Oblinger Childress, C.J., W.T. Foreman, B.F. Connor, and T.J. Maloney, 1999. New Reporting Procedures Based on Long-Term Method Detection Levels and Some Considerationss for Intrepetations of Water-Quality Data Provided by the U.S. Geological Survey National Water Quality Laboratory. U.S. Geological Survey Open-File Report 99-193. http://pubs.er.usgs.gov/usgspubs/ ofr/ofr99193.

Pankow, J.F., 1991. Aquatic Chemistry Concepts. Lewis Publishers, Chelsea, Michigan.

Pankow, J.F., W. Luo, D.A. Bender, L.M. Isabelle, J.S. Hollingsworth, C. Cehn, W.E. Asher, and J.S. Zogorski, 2003. Concentrations and Co-Occurrence Correlations of 88 Volatile Organic Compounds (VOCs) in Ambient Air of 13 Semi-Rural to Urban Locations in the United States. Atmospheric Environment 37(36):5023-5046.

Pankow, J.F., R.E. Rathbun, and J.S. Zogorski, 1996. Calculated Volatilization Rates of Fuel Oxygenate Compounds and Other Gasoline-Related Compounds from Rivers and Streams. Chemosphere 33(5):921-937.

Pankow, J.F., N.R. Thomson, R.L. Johnson, A.L. Baehr, and J.S. Zogorski, 1997. The Urban Atmosphere as a Non-Point Source for the Transport of MTBE and Other Volatile Organic Compounds (VOCs) to Shallow Groundwater. Environmental Science \& Technology 31(10):2821-2828.

Pankow, J.F., L. Wentai, L.M. Isabelle, D.A. Bender, and R.J. Baker, 1998. Determination of a Wide Range of Volatile Organic Compounds (VOCs) in Ambient Air Using Multisorbent Adsorption/Thermal Desorption (ATD) and Gas Chromatography/Mass Spectrometry (GC/MS). Analytical Chemistry 70(24):5213-5221.

Plummer, L.N., R.L. Michel, E.M. Thurman, and P.D. Glynn, 1993. Environmental Tracers for Age-Dating Young Ground Water. In: Regional Ground-Water Quality, W.M. Alley (Editor). Van Nostrand Reinhold, New York City, New York, pp. 255-293.

Rathbun, R.E. and D.Y. Tai, 1988. Application of the Two-Film Model to the Volatilization of Acetone and $t$-Butyl Alcohol from Water as a Function of Temperature. U.S. Geological Survey Water-Supply Paper 2318, 41 pp. http://pubs.er.usgs.gov/usgs pubs/wsp/wsp2318.

Robbins, G.A., S. Wang, and J.D. Stuart, 1993. Using the Static Headspace Method to determine Henry's Law constants. Analytical Chemistry 65(21):3113-3118.

Robinson, K.W., S.M. Flanagan, J.D. Ayotte, K.W. Campo, A. Chalmers, J.F. Coles, and T.F. Cuffney, 2004. Water Quality in the New England Coastal Basins, Maine, New Hampshire, Massachusetts, and 
Rhode Island, 1999-2001. U.S. Geological Survey Circular 1226, 39 pp. http://pubs.usgs.gov/circ/2004/1226/.

Rowe, B.L., S.J. Landrigan, and T.J. Lopes, 1997. Summary of Published Aquatic Toxicity Information and Water-Quality Criteria for Selected Volatile Organic Compounds. U.S. Geological Survey Open-File Report 97-563, 60 pp. http://pubs.er.usgs.gov/ usgspubs/ofr/ofr97563.

Shelton, L.R., 1997. Field Guide for Collecting Samples for Analysis of Volatile Organic Compounds in Stream Water for the National Water-Quality Assessment Program. U.S. Geological Survey Open-File Report 97-401, 20 pp. http://pubs.er.usgs.gov/ usgspubs/ofr/ofr97401.

Squillace, P.J., M.J. Moran, W.W. Lapham, C.V. Price, R.M. Clawges, and J.S. Zogorski, 1999. Volatile Organic Compounds in Untreated Ambient Groundwater of the United States, 19851995. Environmental Science and Technology 33(23):4176-4187.

Squillace, P.J., J.F. Pankow, N.E. Korte, and J.S. Zogorski, 1997. Review of the Environmental Behavior and Fate of Methyl tertButyl Ether. Environmental Science and Technology 16(9):18361844.

Squillace, P.J., J.S. Zogorski, W.G. Wilber, and C.V. Price, 1996. Preliminary Assessment of the Occurrence and Possible Sources of MTBE in Groundwater in the United States, 1993-1994. Environmental Science and Technology 30(5):1721-1730.

USGS (U.S. Geological Survey), 2008. USGS National Water Quality Assessment Data Warehouse. http://water.usgs.gov/nawqa/ data (supplemental data set, self extracting archive), accessed July 2005.

USGS (U.S. Geological Survey), 2009. National Water Information System (NWISWeb). U.S. Geological Survey database. http:// waterdata.usgs.gov/nwis/, accessed July 2006.

Wania, F. and D. MacKay, 1996. Tracking the Distribution of Persistent Organic Pollutants. Environmental Science \& Technology News 30(9):390A-396A.

Weeks, E.P., D.E. Earp, and G.M. Thompson, 1982. Use of Atmospheric Fluorocarbons F-11 and F-12 to Determine the Diffusion Parameters of the Unsaturated Zone in the Southern High Plains of Texas. Water Resources Research 18:1365-1378.

Zogorski, J.S., J.M. Carter, T. Ivahnenko, W.W. Lapham, M.J. Moran, B.L. Rowe, P.J. Squillace, and P.L. Toccalino, 2006. The Quality of Our Nation's Waters-Volatile Organic Compounds in the Nation's Ground Water and Drinking-Water Supply Wells. U.S. Geological Survey Circular 1292. http://pubs.usgs. gov/circ/circ1292/. 